\title{
Preliminary Investigation of Bioplastics from Durian Seed Starch Recovery Using PEG 400 for Reducing Marine Debris
}

\author{
Mirna Apriani ${ }^{*}$, Luqman Cahyono ${ }^{1}$, Agung Prasetyo Utomo², \\ Anggara Trisna Nugraha ${ }^{3}$, Alfira Dwi Cahya Ningrum ${ }^{1}$ \\ 1 Waste Treatment Engineering Study Program, Politeknik Perkapalan Negeri Surabaya, Kampus ITS Sukolilo, \\ Surabaya 60111, Indonesia \\ 2 Design and Construction Engineering Study Program, Politeknik Perkapalan Negeri Surabaya, Kampus ITS \\ Sukolilo, Surabaya 60111, Indonesia \\ ${ }^{3}$ Marine Electrical Engineering Study Program, Politeknik Perkapalan Negeri Surabaya, Kampus ITS Sukolilo, \\ Surabaya 60111, Indonesia \\ * Corresponding author's e-mail: mirnaapriani@gmail.com
}

\begin{abstract}
Plastic is a source of pollution both on land and sea that can disrupt balance of the ecosystem. The characteristic of plastic as a material is difficult to decompose causing problems for environment. Various research needed to produce bioplastics that easily biodegradable in about 60 days. Biodegradable plastics are made from organic materials in the form of starch. Durian seed starch is one of the potential raw materials that can be used as bioplastics. Durian fruit is one of the typical fruits in Indonesia, at present seeds of durian had not been used as raw materials to produce object with economic values. It is necessary to combine the processing of durian seeds through a recovery approach in the form of processing into bioplastics. The aim of study is to analyze the effect of adding PEG 400 as a plasticizer plus calcium carbonate as a solidifier. Tests were carried out on swelling ability, acid and base resistance, tensile strength and biodegradation. The variation of the addition of PEG 400 is $4 \% ; 30 \% ; 50 \%$ and $70 \%$ were carried out to analyze the effect of different concentrations of plasticizers. None of the tensile test results met SNI 7188-11:2018 but all variations had biodegradation values according to SNI 7188-11:2018. Swelling test resulted from $4 \%$ and $30 \%$ are $1.2 \%$ and $2.1 \%$ respectively.
\end{abstract}

Keywords: bioplastics, durian, seed, PEG, intact.

\section{INTRODUCTION}

Non-biodegradable plastics (NBP) released to marine environment potentially harmfulness to inhabitants and cause damage. At present, around 7.8-8.2 million tons of plastics waste enter the oceans every year (Sari et al., 2021). NBP is the biggest part as source of marine debris. Indonesia has generated the amount of plastic waste is growing at unsustainable levels. The accumulation of plastic waste from waterways and coastlines is harming food system and human health. Fishing industry is under threat from increasing levels of marine debris. Plastic waste leaking into oceans could increase to
780,000 tonnes per year if no action is taken by Indonesia. Plastic is one of the valued materials with key role in economy, Indonesia generates around 6.8 million tonnes of plastic waste each year. It is growing by $5 \%$ annually. The projection showed growing of plastic waste flow into water bodies is growing by $30 \%$ between 2017 and 2025 (World Economic Forum, 2020).

Bioplastic is a potential alternative in accordance with environmental sustainability. Synthetic plastic produced by irreversible process causing an environmental burden, microorganisms have not taken apart to degrade petroleumderived polymers. The energy consumption of bioplastic production is lower than petroleum 
polymer, potentially to solve global warming problems (Gironi and Piemonte, 2011)

Due to environmental concerns, replacement conventional plastics with bioplastics became high priority. Plastic based on petroleum can be substituted by using bio-based polymers in order to minimize environmental risk. Green technology conducted using chemistry methodology are able to extract natural polymers, cellulose from vegetable waste. (Moura et al., 2017). Bioplastic can be molded from crop waste, plants, waste from processing fruit, among others, starch, proteins and cellulose are some of the examples as natural polymers materials (Moura et al., 2017; Jara et al., 2018

Among the polymers, starch is abundant, harmless, low cost most and cheaper when comparing with protein, gelatin, poly lactic acid (PLA) and chitosan (Huntrakul et al., 2020-4; Muller et al., 2017; Montero et al., 2017; Chen et al., 2019). Starch is biodegradable and has favorable thermoplastic properties. Polysaccharides is plentiful macromolecules in fauna, is suitable raw material for bioplastics in the form of starch (Imre \& Pukánszky, 2013).

At present, biodegradable plastics from starch have been examined by using banana pile starch, rice starch, corn starch (Shafqat et al., 2021; Zoungranan et al., 2020), potato starch (Beevi et al., 2020), cassava starch (Maulida et al., 2016; Wahyuningtiyas \& Suryanto, 2017, Zoungranan et al., 2020; Huntrakul et al., 2020), jackfruit seed starch (Santana et al., 2018; Wahidin et al., 2021; Retnowati et al., 2015; Lubis et al., 2016), avocado seed starch (Ginting et al., 2018), durian seed starch (Wahidin et al., 2021; Retnowati et al., 2015; Ginting et al., 2016).

Starch has limitations in its application as bioplastics raw material such strength and stiffness usually large, low impact resistance and sensitivity to water. The limitations are generally overcome by plasticization as one of the modification approaches (Imre \& Pukánszky, 2013). Plasticization usually use in modification of raw material to improve processability, to increase deformability through exchange intermolecular bonds to bonds between macromolecules and small molecular weight compound (Bibber et al., 1999). Plasticizer used to destroy crystalline structure of native starch in melt processing as gelatinization ( $\mathrm{Li} \&$ Huneault, 2011). The plasticizers widely used in bioplastics manufacturing such as glycerol, water, urea, sorbitol and formamide (Shafqat et al., 2021; Wilpiszewska \& Spychaj, 2011).
Durian is one of the typical Indonesian fruits, is produced more than 1 million per year (Statistics Indonesia, 2020). At present, seed durian has not been managed optimally, disposed of as solid waste. Otherwise, seed durian has been reported have a high enough starch content around $42.1 \%$ (Baraheng \& Karrila, 2019), can be considered as suitable raw material for bioplastics. Bioplastic research using durian seed starch reported by Wahidin et al., 2021 using glycerol as plasticizer, has resulted edible film which transparency is not required. Durian seed starch used as raw material and glycerol have been used explored resulting biodegradable time approximately $2-4$ weeks (Rozikhin et al., 2020; Irhamni et al., 2014; Retnowati et al., 2015; Jannah et al., 2021). Other plasticizer, polyethylene glycol (PEG) has good solubility in water, stronger, thicker and can increase the value of strain on bioplastic. PEG has several advantages such as non-toxic, odorless, not irritating and not evaporating easily (Syamsu et al., 2007; Rohman, 2016). The usage of PEG400 as plasticizer have been explored with raw material of bioplastic from cassava starch (Syamsu et al., 2007); carrageenan waste (Maulana et al., 2021); palm fruit (Sitompul \& Zubaedah, 2017); jackfruit seed starch (Anas et al., 2016, Santana et al., 2017). The previous research to explore PEG as plasticizer have been widely examine, but application in using durian seed starch has not been investigated so far. It would be a new addition to enrichment in bioplastics from durian seed starch. This research focused on the preparation of extraction starch from durian seed by addition PEG 400 as plasticizer and calcium carbonate. The aim of study is to investigate the quality of bioplastic from durian seed starch by considering the effect of PEG 400 addition. This research was also conducted to identify the potential application of seed durian starch resulting in a research database for designing and manufacturing biodegradable plastics through recovery of waste material.

\section{MATERIALS AND METHODS}

\section{Materials}

This research was conducted using waste from processing of durian from local community. Seed durian collected from home industry processing durian become juice, cake and snacks. Seed durian was peeled and washed before sliced 
and mashed become slurry. Starch was extracted from durian seed slurry by decanting and drying. Molding made of glass with dimensions of $200 \times 200 \mathrm{~mm}$. PEG 400 as plasticizer was food grade otherwise calcium hydroxide, sodium hydroxide, sulphate acid and calcium carbonate were used analytical grade.

This experiment carried out in laboratory scale using slightly modified procedures as outlined below: (a) washed durian seeds (b) peeled the seed coat and sliced (c) soaked the slice seeds with $\mathrm{Ca}(\mathrm{OH})_{2}$ for about 3 hours (d) washed the seed until clean (e) soaked the slice seeds with $\mathrm{Ca}(\mathrm{OH})$, for about 3 hours again (f) washed until free from mucus $(\mathrm{g})$ grinded the seeds in 1:10 ratio weight with water (h) precipitated starch that has mashed (i) disposed water, drying starch sediment during 3 days in sun (depending the weather) (j) refined dry starch completely and sieved mashed starch in 100 mess (k) $5 \mathrm{~g}$ dry starch added by $0.2 ; 2.14 ; 5$ and 11.67 $\mathrm{ml}$ PEG (according research variation 4\%, 30\%, $50 \%$, and $70 \%$, respectively) and $1.5 \mathrm{~g}$ calcium carbonate; (1) heated in $80{ }^{\circ} \mathrm{C}$ and stirred until thickened $(\mathrm{m})$ molded in bioplastic molding, wait until dry.

Soil burial method used for biodegradability test conducted by burying bioplastics sample in dry soil during 15 days (Yaradodi et al., 2016; Marichelvam et al., 2019) observed the decreased of weight. Swelling test investigated water sorption capacity of bioplastic sample was soaked with deionized water at room temperature during 30 minutes. Swelling percentage was calculated based on difference between the weight sample bioplastic after and before soaking (Gonzalez and Igarzabal, 2013). Tensile strength test was conducted according to ASTM D638 for examining bioplastics sample mechanical properties (Jannah et al., 2021).

\section{RESULTS AND DISCUSSION}

\section{Visualization of bioplastics}

Figure 1 showed visualization of bioplastics manufacturing from starch durian, the color was slightly brown and smells like durian. Represent bioplastic with PEG addition variation was (a) $4 \%$, (b) $30 \%$, (c) $50 \%$ and (d) $70 \%$. Figure la captured bioplastics could be removed from mold, was more intact form compared to bioplastics produced in other variations. The usage of PEG $4 \%$ producing bioplastics with physical properties are not rigid, not easily broken but not elastic. In the research variations using 30\% PEG addition (Figure 1b), bioplastics produced were in the form of small part, not intact, not rigid and have no elasticity but still could be removed from mold. On the other hand, bioplastics manufacturing using 50\% (Figure 1c) and 70\% (Figure 1d) PEG addition could not be removed from mold, forming slurry as raw material before molding if picked up. Figure 1 captured physical condition of bioplastic manufacturing from durian seed with PEG addition. The higher concentration of PEG addition, weaker bioplastics physical condition, for further research needed to conduct in order to determine precise PEG addition concentration.

\section{Biodegradation tests}

Bioplastic biodegradability represented bioplastic can be degraded biologically easily with no environmental damage. Bioplastic investigation was buried in soil, had role as a nitrogen and carbon source for microorganism growth. Microorganism consumed bioplastic as its food and increase biomass (Natalie et al., 2008). Based on the result of bioplastic manufacturing, biodegradation test only conducted

c)

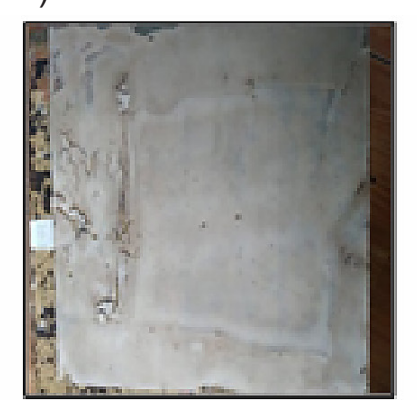

d)

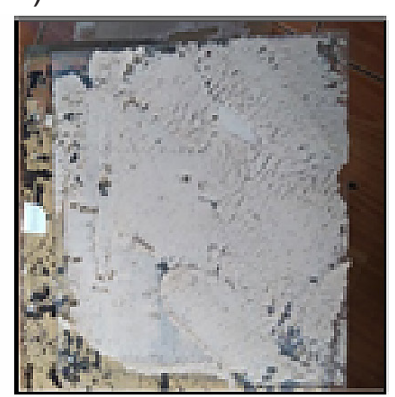

Figure 1. Visualization of bioplastics from durian starch with PEG addition: (a) 4\%, (b) $30 \%$, (c) $50 \%$ and (d) $70 \%$ 
in two variations of PEG 400 addition (4\% and $30 \%)$. The two other variations could not be removed from molding. The results of the biodegradation test reported that addition of $4 \%$ and $30 \%$ PEF was $42 \%$ and $40 \%$, respectivley.

Comparing with Indonesia standard regarding bioplastic in SNI 7188-11:2018, stated that percentable biodegradation value was less than $60 \%$ in a week, the result of bioplastics from durian starch was appropriate with bioplastic quality standard. PEG addition in durian seed starch will bind moisture in the air causing bioplastic easily adsorb water in soil. Swelling durian bioplastic becomes increase causing more easily broken into fragment as well as easily degraded by microorganism like fungi or bacteria in soil (Lu et al., 2009). The hydroxyl (O-H) contains in bioplastic made form starch-based, due to hydrolysis after absorbing water from compost and increased nature decomposition (Wahyuningtiyas and Suryanto, 2018).

\section{Swelling test}

Swelling test conducted due to investigate swelling behavior of bioplastic was emerged in water. The observation could be conducted within two variation research $4 \%$ and $30 \%$ PEG addition. The result shown percentable swelling by calculated weight differences between after and before emerging in water. Bioplastic made from durian seed starch by $4 \%$ and $30 \%$ PEG addition resulting $1.2 \%$ and $2.1 \%$ respectively.

\section{Tensile test}

The examination of mechanical testing only conducted with bioplastic sample manufactured by $4 \%$ PEG addition. Tensile test could be carried out on intact bioplastic condition with size in accordance with test requirement conditions. The tensile strength value was achieved at $1.2 \pm$ $0.2 \mathrm{MPa}$, was not appropriate with SNI standards (24.7-30.2 MPa) for plastic packaging.

Usage PEG as plasticizer with durian seed starch resulted various physical condition of bioplastic. Three of the research variation showed that bioplastic was not intant, two of them was be able to remove from molding. The role of PEG had made fusion in production using chemical polymerization. Chemical polymerization can occur regardless of the raw materials origin, as opposed to natural fermentation that can only take place by the utilization of renewable feedstock (Endres et al., 2017; Karamanlioglu et al., 2017; Kartika et al., 2018). Based on the investigation of this research, higher PEG concentration resulted more melted as slurry. The research variation using PEG addition $50 \%$ and $70 \%$ could be investigated more detailed. Saeful et al. (2018) reported an optimum bioplastics compotition was investigated to be $5 \%(\mathrm{w} / \mathrm{w})$ plasticizer. PEG as a commonly plasticizer, can act as a lubricant during processing (Seggiani et al., 2015). However plasticizer net effects of physical changes could be hard to predict, sometimes resulting low strength bioplastic (Hubbe et al., 2021). Future research needed to examine the compatibility of PEG with durian seed starch and its concentration to be added precise.

\section{CONCLUSIONS}

In conclusion, the study showed that durian seed starch can be recovered as a promising bioplastic in the plastic advancement. PEG also can be utilized as plasticizer with calcium carbonate addition to manufacture biodegradable plastics. Furthermore, future research is needed to determine the precise concentration of PEG in order to develop intact plastic form environmentally friendly bioplastics due to its environmental benefits.

\section{Acknowledgements}

The authors gratefully acknowledge to Shipbuilding Polytechnic of Institute Surabaya for the grant which made this research work.

\section{REFERENCES}

1. Anas A.K., Ariefta N., Nurfiana Y., Rohaeti E.2016. Pengaruh Penambahan 1,4-Butanadiol dan Polietilen Glikol (PEG) 1000 terhadap Kemudahan Biodegradasi Bioplastik dari Biji Nangka (Artocarpus heterophyllus). Jurnal Eksakta, 16(2), 115-123.

2. Baraheng S., Taewee T. Karrila. 2019. Chemical and functional properties of durian (Durio zibethinus Murr.) Seed flour and starch. Food Bioscience, 30(2), 100412.

3. Beevi R.K., Fathima A.R.F., Fathima A.I A., Noorjahan T. M., Deepika T. C.M. 2020. Bioplastic synthesis using banana peels and potato starch characterization. International Journal of Scientific \& Technology Research, 9(1).

4. Bibers I., Tupureina V., Dzene A., Kalnins M. 1999. 
Improvement of the deformative characteristics of poly-b-hydroxybutyrate by plasticization. Mech Compos Mater, 35(4), 357-364.

5. Chen J., Chen F., Meng Y., Wang S., Long Z. 2019. Oxidized microcrystalline cellulose improve thermoplastic starch-based composite films: Thermal, mechanical and water-solubility properties. Polymer, 168, 228-235.

6. Endres H.J., 2019. Bioplastics, In: K. Wagemann and N. Tippkötter (Eds.) Biorefineries. Springer International Publishing: Cham, Switzerland, 427-468.

7. Ginting M.H.S., Hasibuan R., Lubis M,, Alanjani F,. Winoti F.A., Siregar R.C. 2018. Utilization of Avocado Seeds as Bioplastic Films Filler Chitosan and Ethylene Glycol Plasticizer. Asian Journal of Chemistry, 30(7), 1569-1573.

8. Gironi F., Piemonte V. 2011. Bioplastics and petroleum-based plastics: strengths and weaknesses. Energy Sources, Part A, 33, 1949-1959.

9. González A., Igarzabal A.C. 2013. Soy protein-Poly (lactic acid) bilayer films as biodegradable material for active food packaging. Food Hyd, 33(2), 289-296.

10. Hendra M.S., Ginting, Kristiani M., Amelia Y., Hasibuan R. 2016. The Effect of Chitosan, Sorbitol, and Heating Temperature Bioplastic Solution on Mechanical Properties of Bioplastic from Durian Seed Starch (Durio zibehinus). Int. Journal of Engineering Research and Applications, 6(1), 33-38.

11. Hongbo L., Huneault, M.A., 2011. Comparison of sorbitol and glycerol as plasticizers for thermoplastic starch in TPS/PLA blends. Journal of Applied Polymer Science, 119, 2439-2448.

12. Hubbe M.A., Lavoine N., Lucian A., Lucia, Dou C. 2021. Formulation bioplastic composite for biodegradability, recycling, and performance: a review. Bioresources, 16(1), 2021-2083.

13. Huntrakul K., Yoksan R., Sane A., Harnkarnsujarit N. 2020. Effects of pea protein on properties of cassava starch edible films produced by blown-film extrusion for oil packaging. Food Packaging and shelf life, 24, 100480

14. Imre B., Pukánszky B. 2013. Compatibilization in bio-based and biodegradable polymer blends, European Polymer Journal, 49(6), 1215-1233.

15. Irhamni, Rambe M.S., Zulfalina, Rahmi. 2014. Analisa pengaruh pati biji durian durian (Durio zibethinus) sebagai bahan pengisi terhadap sifat mekanik dan biodegradasi komposit matrik polipropilena (PP). Jurnal Teori dan Aplikasi Fisika, 2(2).

16. Jannah N.R., Jamarun N., Putri Y.E. 2021. Production of starch-based bioplastic from durio zibethinus murr seed using glycerol as plasticizer. J. Ris. Kim., 12(2).

17. Karamanlioglu M., Preziosi R., Robson G.D. 2017.
Abiotic and biotic environmental degradation of the bioplasticpolymer poly(lactic acid): A review. Polym. Degrad. Stab., 137, 122-130.

18. Kartika T.,.Harahap M.B., Ginting S.M.H. 2018. Utilization of mango seed starch in manufacture of bioplasti reinforced with microparticle clay using glycerol as plasticizer. IOP Conf. Ser. Mater. Sci. Eng., 309.

19. Lu D.R., Xiao C.M., Xu S.J. 2009. Starchbased completely biodegradable polymer materials. Express Polym. Lett., 3(6), 366-375.

20. Lubis M., Harahap M. B., Manullang, Alfarodo, Ginting M.H.S., Sartika, Sartika M. 2016. Utilization starch of jackfruit seed (Artocarpus heterophyllus) as raw material for bioplastics manufacturing using sorbitol as plasticizer and chitosan as filler. 2016. Journal of Physics: Conference Series, 801, International Conference on Computing and Applied Informatics, Medan, Indonesia 2016, 14-15.

21. Marichelvam M.K., Jawaid M., Asim M. 2019. Corn and rice starch-based bio-plastics as alternative packaging materials. Fibers, 7(4), 1-14.

22. Maulana D.S., Mubarak A.S., Pujiastuti D.Y. 2021. The concentration of polyethylen glycol (PEG) 400 on bioplastic cellulose based carrageenan waste on biodegradability and mechanical properties bioplastic. OP Conf. Series: Earth and Environmental Science, 679, 012008.

23. Maulida M., Siagian, Tarigan P. 2016. Production of Starch Based Bioplastic from Cassava Peel Reinforced with Microcrystalline Celllulose Avicel PH101 Using Sorbitol as Plasticizer. Journal of Physics: Conference Series, 710, 012012.

24. Montero B., Rico M., Rodríguez-Llamazares S., Barral L., Bouza R. 2017. Effect of nanocellulose as a filler on biodegradable thermoplastic starch films from tuber, cereal and legume. Carbohydrate polymers, 157, 1094-1104.

25. Mostafa N.A., Farag A.A., Abo-dief H.M., Tayeb A.M. 2018. Production of biodegradable plastic from agricultural wastes. Arabian Journal of Chemistry, 11, 546-553.

26. Moura I.G., de Sá, A.S., Abreu A.S.L.M, Machado A.V.V, 2017. Bioplastics from agro-wastes for food packaging applications. Academic Press, 223-263.

27. Muller J., González-Martínez C., Chiralt A., Muller J., González-Martínez C., Chiralt A. 2017. Combination of poly(lactic) acid and starch for biodegradable food packaging. Materials, 10(8), 952.

28. Nathalie L., Christophe B., Christian B. 2008. Polymer biodegradation: Mechanisms and estimation techniques. Chemosphere, 73(4), 429-442.

29. Retnowati D.S., Ratnawati R, Purbasari A. 2015. A biodegradable file from jackfruit (Artocarpus heterophyllus) and durian (Duriozibethinus) seed flours. Scientific 
Study \& Research Chemistry \& Chemical Engineering, Biotechnology, Food Industry, 16(4), 395-404.

30. Rohman M.A. 2016. Pengaruh penambahan glutaraldehida terhadap karakteristik film bioplastik kitosan terplastis carboxy methyl cellulose (CMC) skripsi. Surabaya: Universitas Airlangga, 9.

31. Rozikhin, Zalfiatri Y., Hamzah F.H. 2020. Pembuatan Plastik Biodegradable Dari Pati Biji Durian dan Pati Biji Nangka. Chempublish Journal, 5(2), 151-165.

32. Saiful, Helwati H., Saleha S., Iqbalsyah T.M. 2018. Development of bioplastic from wheat Janeng starch for food packaging. In: Proceedings of the 8th Annual International Conference (AIC) 2018 on Science and Engineering, Aceh, Indonesia, 12-14.

33. Santana R.F., Bonomo R., Gandolfi O., Rodrigues L.B., Santos L.S., Pires D.S., Oliveira C.P., da Costa Ilhéu Fontan R., Veloso C.M. 2018. Characterization of starch-based bioplastics from jackfruit seed plasticized with glycerol. Journal of Food Science and Technology, 55(1), 278-286. https://doi. org/10.1007/s13197-017-2936-6

34. Santana R.F., Bonomo R.C.F., Gandolfi O.R.R. 2018. Characterization of starch-based bioplastics from jackfruit seed plasticized with glycerol. 2018. Journal of Food Science and Technology, 55, 278286. https://doi.org/10.1007/s13197-017-2936-6

35. Sari G.L., Kasasiah A., Utami M.R., Trihadiningrum Y. 2021. Microplastics ontamination in the aquatic environment of Indonesia: A comprehensive review. Journal of Ecological Engineering, 22(10), 127-140.

36. Seggiani M., Cinelli P., Verstichel S., Puccini M., Vitolo S., Anguillesi I., Lazzeri A. 2015. Development of fibres-reinforced biodegradable composites. In: S. Pierucci and J.J. Klemes (Eds.) Proceedings of the 12th International Conference on Chemical \& Process Engineering, 43, 1813-1818.

37. Shafqat A., Al-Zaqri N., Tahir A., Alsalme A. 2021. Synthesis and characterization of starch based bioplatics using varying plant-based ingredients, plasticizers and natural fillers. Saudi Journal of Biological Sciences, 28(3), 1739-1749.

38. Sitompul, Zubaidah. 2017. The influence of the type and concentration of plasticizer toward physical characteristic of edible film from palm fruit (Arenga pinnata). Jurnal Pangan dan Agroindustri, 5(1), 13-25.

39. Syamsu K., Hartoto L., Fauzi A.M., Suryani A., Rais D. 2007. The roles of PEG400 in the introduction of bioplastic polyhydroxy alkanoates produces by Rastonia Eutropha from hydrolysed sago starch substrate. Jurnal Ilmu Pertanian Indonesia, 12(2), 63-68.

40. Wahidin M., Srimarlita A., Sulaiman I., Indarti E. 2021. Transparency and thickness of jackfruit and durian seed starch edible film. IOP Conf. Series: Earth and Environmental Science, 667, 012030.

41. Wahyuningtiyas N.E., Suryanto H. 2017. Analysis of biodegradation of bioplastics made of cassava starch. Journal of Mechanical Engineering Science and Technology, 1(1).

42. Wahyuningtiyas N.E., Suryanto H. 2018. Properties of cassava starch based bioplastic reinforced by nanoclay. Journal of Mechanical Engineering Science and Technology, 2(1), 20-26.

43. Wilpiszewska K., Spychaj T. 2011. Ionic liquids: Media for starch dissolution, plasticization and modification. Carbohydrate Polymers, 86(2), 424-428.

44. World Economic Forum. 2020. Radically reducing plastic pollution in Indonesia: A Multi stakeholder action plan. National Plastic Action Partnership, Switzerland.

45. Zoungranan Y., Lynda E., Dobi-Brice K.K., Tchirioua E., Bakary C., Yannick D.D. 2020. Influence of natural factors on the biodegradation of simple and composite bioplastics based on cassava starch and corn starch. Journal of Environmental Chemical Engineering, 8(5), 104396. 